Univerzitet u Beogradu
Poljoprivredni fakultet
Institut za poljoprivrednu tehniku
Naučni časopis
POLJOPRIVREDNA TEHNIKA
Godina XLIII
Broj 1, 2018.
Strane: $22-28$

UDK: 621.22

Original research paper

\title{
CFD SIMULATION OF THE FLOWING PROCESS THROUGH THE SHORT LENGTH SHARP EDGED ORIFICES
}

\author{
Sasko S. Dimitrov ${ }^{1}$, Zoran M. Dimitrovski ${ }^{1 *}$ \\ Goce Delcev University, Faculty of Mechanical Engineering - Stip, Macedonia
}

\begin{abstract}
In this paper the static characteristics of the sharp edged orifices have been investigated. Mathematical relationship between pressure loss and flow through the orifice has been developed and solved for this type of orifices. A CFD simulation of the flowing process has been done. Full CAD model of the volume for orifices with different geometric parameters was created and meshed at finite number of elements. As a result of the CFD computations, few diagrams have been presented and compared to the theoretical ones. The discharge coefficient and the pressure loss coefficient have been obtained.
\end{abstract}

Key words: orifice, pressure drop, flow, CFD, simulation, discharge coefficient.

\section{INTRODUCTION}

The flowing and pressure drop through the sharp edged short orifices have been investigated long time ago. In [2] a model for discharge coefficient in the orifice is introduced as a function of the Reynolds number. According to this model, discharge coefficient calculation requires iterative procedure because Reynolds number also depends on the flow rate. To avoid this iterative procedure, in [3] an empirical discharge coefficient model for orifice flow is recommended. Another model for the discharge coefficient is described in [4] by Borutzky. Those models provide a linear relation through the orifice for small velocities while for turbulent flows, they match the conventional square root characteristics. Also, the transition from the laminar to the turbulent regime is smooth [5].

\footnotetext{
${ }^{1 *}$ Corresponding author: Email: zoran.dimitrovski@ugd.edu.mk
} 
In this paper a CFD method for simulation of the flowing process through the orifice is used, the pressure drop coefficient and the discharges coefficient have been determined and compared with numerical ones.

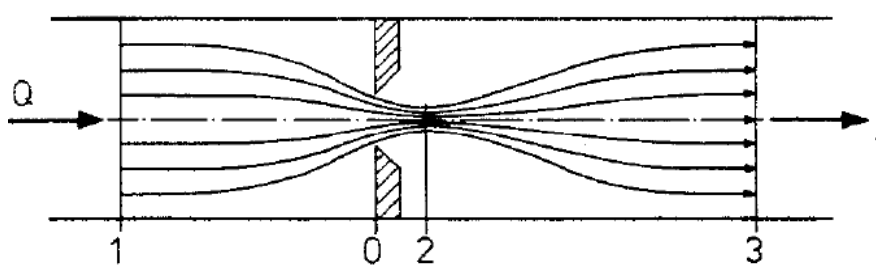

Figure 1. The short length sharp edged orifice

\section{MATHEMATICAL MODELING}

Steady state flowing process through an orifice is presented in figure 1 . Well known dependence on flow of the pressure drop is [6]:

$$
Q=\alpha_{D} \cdot A_{0} \cdot \sqrt{\frac{2}{\rho} \cdot \Delta p}
$$

where: $Q$-the flow through the orifice; $\alpha_{D}$ - the discharge coefficient; $A_{0}$ - the area of the orifice, $\Delta p=p_{1}-p_{3}$ - the pressure drop in the orifice.

Pressure drop in the sharp edged short orifice can be expressed by the equation:

$$
\Delta p=\xi \cdot \frac{\rho}{2 \cdot A_{0}} \cdot Q^{2}
$$

Where: $\xi$ - the local resistant coefficient.

Comparing the eq. (1) and (2), the dependence among the discharge coefficient and the pressure drop coefficient, is:

$$
\alpha_{D}=\frac{1}{\sqrt{\xi}}
$$

For $R e=10-20000$ and $l / d=1.5-10$, Lichtarowicz [7] has recommended an expression for discharge coefficient calculation:

$$
\frac{1}{\alpha_{D}}=\frac{1}{\alpha_{D \max }}+\frac{20}{R e} \cdot\left(1+2.25 \cdot \frac{l}{d}\right)
$$

Where $d$ - the orifice diameter; $l$ - the orifice length. 
Experimentally Wobben [8] has determined the maximal value of the discharges coefficient and it is $\alpha_{\text {Dmax }}=0.83$.

Reynolds number for circle area is $=\frac{v \cdot d}{v}=\frac{4 \cdot Q}{d \cdot \pi \cdot v}$. Combining the last eq. for $R e$, into eq. (4) and introducing the correction factor $\left[\frac{20 \cdot v}{d} \cdot(1+2.25 \cdot(l / d))\right]^{2}$, the final equation for flow calculation in a sharp edged orifice has been obtained:

$$
\begin{aligned}
Q=\alpha_{D \max } & \frac{\pi \cdot d^{2}}{4} \cdot \sqrt{\frac{2}{\rho} \cdot \Delta p+\left[\frac{20 \cdot v}{d} \cdot(1+2.25 \cdot(l / d))\right]^{2}-} \\
& -\alpha_{D \max } \cdot 5 \cdot \pi \cdot d \cdot v \cdot\left(1+2.25 \cdot \frac{l}{d}\right)
\end{aligned}
$$

Knowing the geometric parameters of the orifice, applying eq. (5), it is possible to obtain the static characteristic of the orifice, i.e. the flow through the orifice depending on the pressure drop in the orifice.

\section{CFD SIMULATION OF THE FLOWING PROCESS THROUGH THE ORIFICES}

To identify the discharge coefficient and the pressure drop in the orifice, a series of steady-state CFD computations was performed with commercial CFD software package FLUENT. Three different sizes of orifices have been investigated: $0.6 \mathrm{~mm}, 0.8 \mathrm{~mm}$ and $1.0 \mathrm{~mm}$. CAD model of the fluid volume has been created and it has been divided into around 310000 elements, depending on the size of the orifice. The meshing model of the $0.8 \mathrm{~mm}$ orifice is presented on figure 2 .

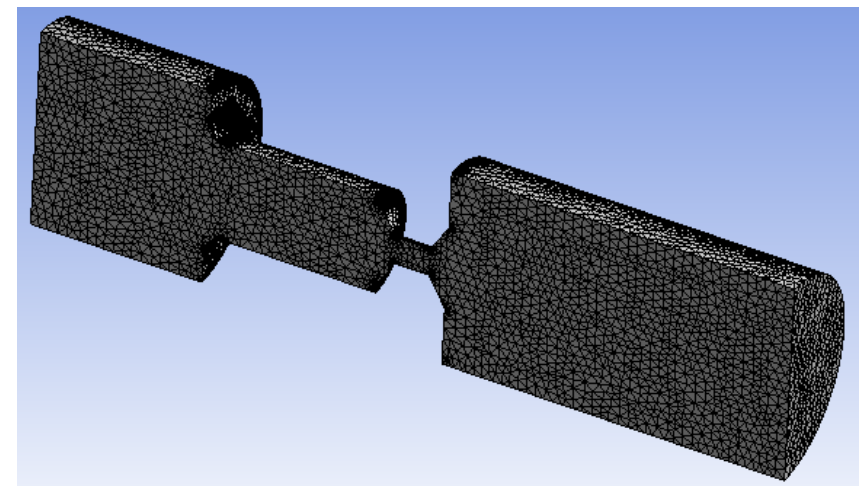

Figure 2. The CFD meshed geometry

As an input parameter was set the flow in the orifice. The output parameter, calculated by FLUENT, is the pressure drop through the orifice. 
The results obtained by CFD simulation and the solution of the eq. (5) have been shown on fig.3. It is evident that there in very good match of the results between CFD simulation and the presented theory.

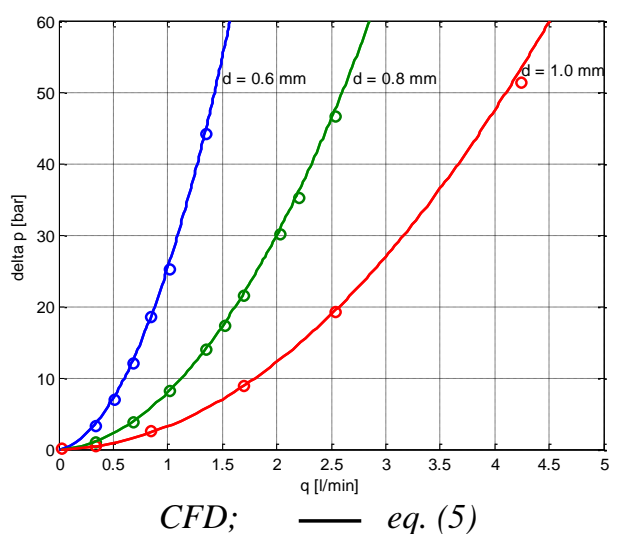

Figure 3. The static characteristics of the orifices

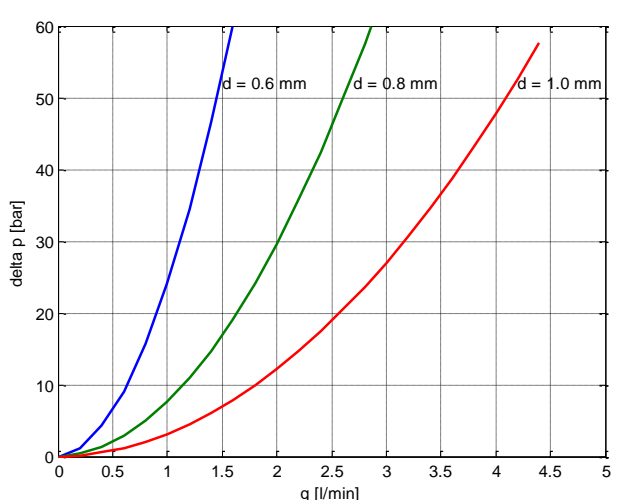

Figure 4. The theoretical static characteristics of the orifices

For simplicity of calculation, very often the pressure drop in the sharp edged orifice can be approximated by the eq. (2). According to this relation, for the local resistant coefficient $\xi=1.48$, the curves on figure 5 have been obtained. It can be seen that there is good match between CFD simulation and relation (5) (figure 3) and the approximated eq. (2) figure 4. Applying the eq.(3), the flow coefficient is $\alpha_{D}=0.822$, i.e. it tends to $\alpha_{\text {Dmax }}=0.83$

The values of the flow coefficient depending on the Reynolds number have been presented on figure 5. For turbulent regime of flowing the flow coefficient has constant value, but in the laminar regime of flowing, the flow coefficient is not constant, i.e. it varies depending on the average velocity of flowing in the orifice. If it is supposed using this sharp edged orifices in pilot pressure relief valves, usually the pilot flow in the pressure relief valves is around $1.0-1.5[\mathrm{l} / \mathrm{min}]$. So the $R e$ number does not exceed the value of 1500 . For simplicity of calculation, in the dynamic model of the pilot operated pressure relief valve an average value of 0.8 for flow coefficient can be taken. 


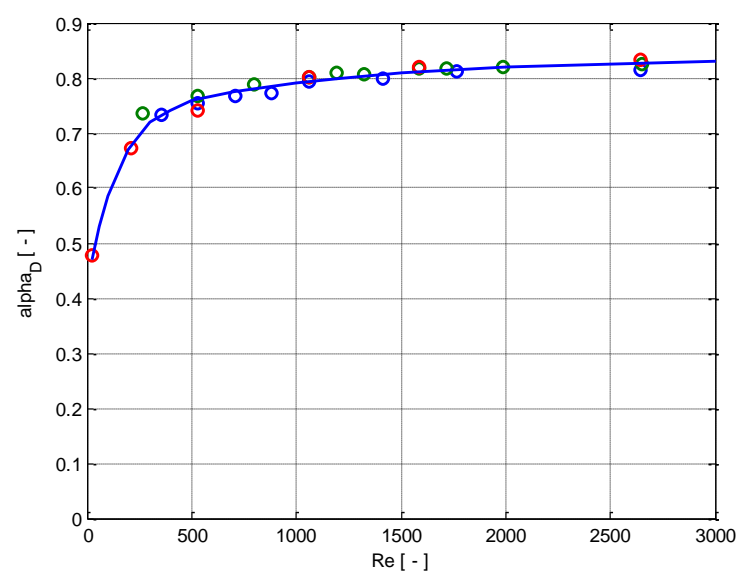

CFD; approximation

Figure 5. The discharge coefficient of the orifices

Figure 6 and figure 7 depict the pressure and velocity distribution for $0.8 \mathrm{~mm}$ sharpedged orifice along the axis of the orifice. The pressure and velocity distribution do not differ qualitatively for different orifice diameters. The pressure drops quickly in the nozzle, then at the end of the nozzle the pressure little increase and then decrease and stay approximately constant. The velocity sharply rises in the nozzle and at the end of the nozzle begins to decrease.

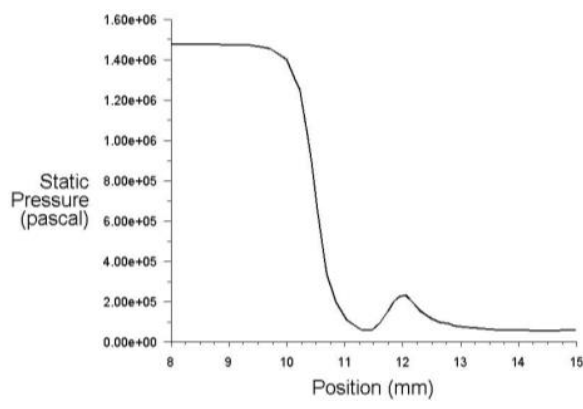

Figure 6. The pressure distribution along the orifice axis

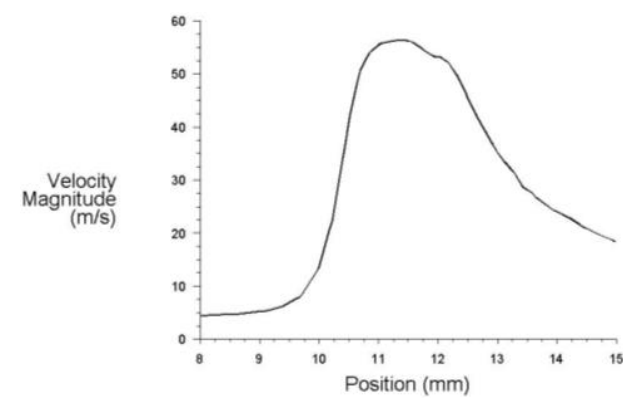

Figure 7. The velocity distribution along the orifice axis

Typical velocity contour and velocity vectors of $0.8 \mathrm{~mm}$ orifice diameter, with $1.35 \mathrm{l} / \mathrm{min}$ and 14 bar pressure drop in the orifice is presented on figure 8 and figure 9 . The velocity contours and velocity vectors do not differ qualitatively for different orifice diameters. As it is expected, the maximal velocity occurs at the nozzle where the diameter is the lowest. 


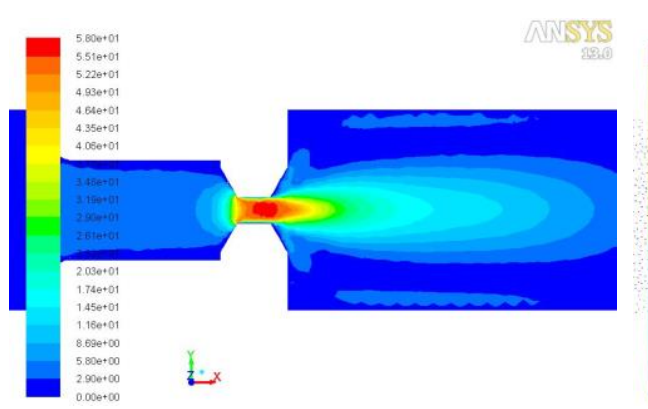

Figure 8. The velocity contour

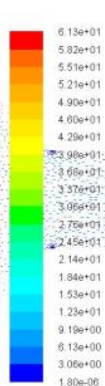

Figure 9. The velocity vectors

\section{CONCLUSIONS}

Mathematical relationship between flow and pressure loss in the sharp edged orifices has been developed in this paper. This mathematical model was confirmed with CFD simulation. CAD model of the flowing volume was created and simulation of the flowing process has been made. Graphically was compared the results of the CFD simulation and the solution of the eq. (5). The flow coefficient depending on the Reynolds number was obtained and presented graphically on fig.5. It can be seen that increasing the Re number the discharge coefficient tends to the value of 0.83 The pressure and velocity distribution along the orifice axis was depicted and the velocity contour and velocity vectors were shown (figure 8 and figure 9).

\section{REFERENCES}

[1] Komitovski, M., Dimitrov, S. 2013. “ Transient response process of a pilot operate pressure relief valve”, XVIII National Scientific with International Participation, FPEPM 2013, Sozopol, Bulgaria, pp. 139-145.

[2] Meritt, H.E., 1967. "Hydraulic Control Systems", John Wiley and Sons, 1967, 39-45.

[3] Wu, D., Burton, R., Schoenau, G. 2002. "An Empirical Discharge Coefficient Model for Orifice Flow", International Journal of Fluid Power - ISSN 1439-9776, Vol. 3, No. 3, 17-24.

[4] Borutzky, W., Barnard, B., Thoma, J. 2002. "An orifice flow model for laminar and turbulent conditions", Simulation Modelling Practice and Theory, Elsevier Science B. V., Vol. 10, 2002. pp.141-152.

[5] Hos, C. 2005. "Dynamic Behavior of Hydraulic Drives", Dissertation, Department for Hydrodynamic Systems, Budapest Univ. of Technology and Economics, Budapest, pp.16-23.

[6] Backé, W., Murrenhoff, H. 1994. “ Grundlagen der Ölhydraulik. Institut für fluidtechnische Antriebe und Steuerungen“, Technische Hochschule Aachen, pp. 26-28.

[7] Lichtarowicz, A., Duggins, R., Markland, E. 1965. "Discharge Coefficients for Incompressible NonCavitating Flow Through Long Orifices", J. Mech. Eng. Sc. Nr. 2, pp. $210-219$.

[8] Wobben, G.D. 1978. "Statisches und dynamisches Verhalten vorgesteuerter Druckbegrenzungsventile unter besonderer Berücksichtigung der Strömungskräfte“, Dissertation, RWTH Aachen, pp. 21-27. 


\title{
CFD SIMULACIJA PROTOKA FLUIDA KROZ KRATKE PRIGUŠNICE SA OŠTRIM IVICAMA
}

\author{
Sasko S. Dimitrov, Zoran M. Dimitrovski
}

Universitet Goce Delcev, Mašinski fakultet - Štip, Republika Makedonija

Sažetak: U radu su istražene statičke karakteristike protoka fluida u prigušnicima oštrih ivica. Za ovaj tip otvora razvijen je i rešen matematički odnos gubitka pritiska i protoka kroz otvore. Prikazana i urađena je CFD simulacija protoka. Izrađen je CAD model zapremina protoka sa različitim geometrijskim parametrima podeljen konačnim brojem elemenata. Kao rezultat CFD proračuna, prikazani su dijagrami koji su upoređeni sa teoretskim dijagramom. U proračunu su dobijeni koeficijent protoka i koeficijent gubitka pritiska.

Key words: prigušnice, pad pritiska, protok, CFD simulacija, koeficijent protoka.

Prijavljen:

18.02 .2018

Ispravljen:

18.03 .2018

Prihvaćen: $\quad$ 23.03.2018 